ББК 63.4

$$
\begin{gathered}
\text { Организация конференции и издание материалов проведены } \\
\text { при финансовой поддержке Российского фонда фундаментальных исследований, } \\
\text { проект № 19-09-20008 }
\end{gathered}
$$

Утверждено к печати Ученым советом ИИМК РАН

Редакционная коллегия тома II: А. В. Поляков, Е. С. Ткач (отв. редакторы), М. Т. Кашуба, Л. Б. Кирчо, Е. А. Черлёнок, В. Я. Стёганцева, А. И. Климушина

Рещензенты: д. и. н. Л. Б. Вишняцкий, д. и. н. А. А. Выборнов

Программный комитет конференции: академик РАН, д. и. н., проф. М. Б. Пиотровский (Государственный Эрмитаж, почетный председатель); д. и. н. В. А. Лапшин (ИИМК РАН, председатель); д. и. н. А. В. Головнёв (МАЭ РАН, сопредседатель); д. и. н. В. А. Дергачёв (Высшая антропологическая школа, Молдова, сопредседатель); д. и. н. И. Ф. Попова (ИВР РАН, сопредседатель); академик АН Республики Узбекистан, д. и. н., проф. Э. В. Ртвеладзе (сопредседатель); к. и. н. А. В. Поляков (ИИМК РАН, зам. председателя); к. и. н. В. А. Алёкшин (ИИМК РАН, зам. председателя); д. и. н. Ю. Е. Берёзкин (МАЭ РАН); Dr., Prof. Н. Бороффка

(Германский археологический институт, Германия); В. С. Бочкарёв (ИИМК РАН);

Dr. Э. Кайзер (Свободный университет Берлина, Германия); к. и. н. М. Т. Кашуба (ИИМК РАН); д. и. н. Л. Б. Кирчо (ИИМК РАН); к. и. н. А. В. Кияшко (Южный федеральный университет); к. и. н. П. Ф. Кузнецов (СГСПУ); к. и. н. Н. М. Малов (СНИГУ); к. и. н. В. П. Никоноров (ИИМК РАН); Ю. Ю. Пиотровский (Государственный Эрмитаж); д. и. н., проф. Д. Г. Савинов (Институт истории СПбГУ); к. и. н. В. Н. Седых (Институт истории СПбГУ); к. и. н. Н. Н. Скакун (ИИМК РАН); к. и. н. Н. Ф. Соловьёва (ИИМК РАН); к. и. н. А. И. Торгоев (Государственный Эрмитаж); к. и. н. Е. А. Черлёнок (Институт истории СПбГУ)

Организационный комитет конференции: к. и. н. А. В. Поляков (ИИМК РАН, председатель); к. и. н. В. А. Алёкшин (ИИМК РАН, зам. председателя); В. С. Бочкарёв (ИИМК РАН); к. и. н. М. Т. Кашуба (ИИМК РАН); д. и. н. Л. Б. Кирчо (ИИМК РАН);

А. И. Климушина (ИИМК РАН, отв. секретарь); к. и. н. В. П. Никоноров (ИИМК РАН); Ю. Ю. Пиотровский (Государственный Эрмитаж); В. Я. Стеганцева (ИИМК РАН); В. В. Терёхина (ИИМК РАН, МАЭ РАН, отв. секретарь); к. и. н. Е. С. Ткач (ИИМК РАН); И. Ж. Тутаева (Государственный Эрмитаж); к. и. н. Е. А. Черлёнок (Институт истории СПбГУ)

Древности Восточной Европы, Центральной Азии и Южной Сибири в контексте связей и взаимодействий в евразийском культурном пространстве (новые данные и концепции): Материалы Международной конференции, 18-22 ноября 2019 г., Санкт-Петербург. Т. ІІ. Связи, контакты и взаимодействия древних культур Северной Евразии и цивилизаций Востока в эпоху палеометалла (IV-I тыс. до н. э.). К 80-летию со дня рождения выдающегося археолога В. С. Бочкарёва. - СПб.: ИИМК РАН, Невская Типография, 2019. - 287 с.

ISBN 978-5-907053-35-9

DOI 10.31600/978-5-907053-35-9 


\title{
Литература
}

Бекназаров Р. А. 2010. Казахи Северного Приаралья в XIX - начале XX вв. (историко-этнографическое исследование): автореф. дис. ... д-ра. ист. наук. Алматы.

Бочкарёв В. С.2010. Погребениялитейщиков эпохи бронзы (методологический пересмотр)// Культурогенез и древнее металлопроизводство Восточной Европы. СПб. С. 209-211.

Бочкарёв В. С. 2012. К вопросу об использовании металлических серпов и серповидных орудий в степных (скотоводческих) культурах эпохи бронзы Восточной Европы // PAЕ. № 2. С. 194-214.

Дергачёв В. А., Бочкарёв В. С. 2002. Металлические серпы поздней бронзы Восточной Европы. Кишинёв.

Граков Б. Н. 1935. Работы в районе проектируемых южноуральских гидроэлектростанций // Археологические работы Академии на новостройках в 1932-33 гг. Ч. 2. М.; Л. С. 68-77 (Известия ГАИМК. Вып. 110).

\section{SICKLES AND HAMMERS FROM BURIAL COMPLEXES OF THE LATE BRONZE AGE IN THE SOUTHERN SPURS OF THE URAL MOUNTAINS}

Vitaliy V. Tkachev

Orenburg Federal Research Center, Ural Branch of RAS, Orenburg, Russia

Keywords: Southern Urals, Alakul culture, burials with manufacturing tools, harvesting tools, mining-metallurgic tools.

In the steppe Ural region and at the northern periphery of the Ural-Mugodzhar district, a series of burials of the Sintashta and Alakul cultures were excavated, where metal sickle-like artifacts and stone tools for mining-metallurgic manufacture were found. In all the funerary complexes under discussion, these categories of objects accompanied adult males of a mature age reflecting their involvement in the most significant branches of industry. Harvesting tools used for laying-in of hay and leaf and branch fodder, are related with cattle breeding which was the basis of the system of life sustenance. Stone hammers, pestles and anvils indicate mining-metallurgic occupations of the interred. In Sintashta burials, the tools related to metallurgic production constitute a representative collection reflecting the heritage of cultures of the Middle Bronze Age where burials of metal-casters are recorded. At necropoleis of the Alakul culture, tools of this kind are very rarely met with - here the tendency to exclude markers of the production specialization from the funerary practice is traceable.

\section{ПРОИСХОЖДЕНИЕ И РАЗВИТИЕ КУЛЬТУРЫ ТЕКСТИЛЯ В ПОЗДНЕМ БРОНЗОВОМ ВЕКЕ ЮЖНОГО УРАЛА ${ }^{1}$}

\author{
П. С. Медведева \\ Южно-Уральский государственный гуманитарно-педагогический университет, \\ Челябинск, Россия
}

DOI: $10.31600 / 978-5-907053-35-9-268-270$

Ключевые слова: текстиль, бронзовый век, Южный Урал, отпечатки ткани.

Культура текстиля - это совокупность характерных особенностей текстильного продукта и технологий его изготовления, обусловленная социально-экономическими

\footnotetext{
${ }^{1}$ Работа выполнена при финансовой поддержке РФФИ, проект № 18-09-00015, «“Золотое руно” бронзового века Северной Евразии: анализ культурного, географического и хронологического контекста».
} 
особенностями, культурными, эстетическими и ценностными предпочтениями общества (Harris 2012). Анализ отпечатков тканей на синташтинских, петровских и алакульских сосудах и фрагментов археологического текстиля позволяет выделить следующие элементы культуры текстиля у населения позднего бронзового века Южного Урала.

1. Сырье для тканей было в основном животного происхождения. Учитывая скотоводческую направленность хозяйства и высокий процент овец в стаде (Косинцев и др. 2016), базисом для местного текстильного производства была овечья шерсть, при некоторой доле импортного растительного волокна.

2. Использовался плетеный, витой и тканый текстиль из пряденых нитей, преимущественно Z-крутки. Ткани представлены различными вариантами полотняного переплетения (сбалансированные тонкие и грубые, несбалансированные тонкие и грубые). Тесьма встречается диагонально-полотняного и диагонально-саржевого переплетения; шнуры изготовлены витьем из четырех и восьми нитей.

3. Декорирование осуществлялось при помощи красных красителей (марены или подмаренников), комбинаций естественных цветов овечьей шерсти, вариаций крутки, вышивки.

4. Текстиль применялся в изготовлении одежды и аксессуаров костюма (сумочках), а также в керамическом производстве.

Большинство технологий не находят истоков в производстве энеолитического периода истории Южного Урала. Применение шерстяного сырья и операции его обработки, окрашивание мареной, ткачество появляются здесь впервые в начале II тыс. до н. э. и связаны с синташтинским импульсом. Ближайшие аналогии в единичных случаях прослеживаются в катакомбных памятниках: использование шерстяного волокна, тесьмы в конструкции головного убора, распространение текстильных элементов в костюме (Shishlina et al. 2005).

Синташтинские технологии наследуют петровское и алакульское население. На это указывают единство характеристик тканей, используемый для их производства орудийный комплекс, устойчивость и высокий уровень развития текстильного производства на всех этапах. Тем не менее, на протяжении первой половины II тыс. до н. э. происходило постепенное смещение преобладающих типов тканей от сбалансированных в синташтинский период до тонких несбалансированных в алакульское время.

Культура текстиля Южного Урала в позднем бронзовом веке входила в единый технологический массив степной и лесостепной полосы срубно-андроновского «мира», а также, возможно, и связанных с ним «андроноидных» лесных культур. Это единство могло быть обусловлено скотоводческим хозяйственно-культурным типом производящей экономики, общими импульсами сложения популяций и традициями индоиранской языковой семьи.

\section{Литература}

Косинцев П. А., Бачура О. П., Рассадников А. Ю., Кисагулов А. В. 2016. Животноводство у населения Южного Зауралья в эпоху поздней бронзы // Удальцов С. Н. (отв. ред.). Динамика современных экосистем в голоцене: Материалы IV Всерос. науч. конф. М. С. 102-104.

Harris S. 2012. From the parochial to the universal: comparing cloth cultures in the Bronze Age. In: European Journal of Archaeology. Vol. 15 (1). P. 61-97.

Shishlina N. I., Orfinskaya O. V., Golikov V. P. 2005. Headdress from the Catacomb Culture Grave of the Shakhaevskaya Burial Ground in the Rostov Region. In: Archaeological Textiles Newsletter. No. 40. P. 6-9. 


\title{
THE ORIGIN AND DEVELOPMENT OF THE TEXTILE CULTURE IN THE LATE BRONZE AGE OF THE SOUTHERN URALS
}

Polina S. Medvedeva

South Ural State Humanitarian Pedagogical University, Chelyabinsk, Russia

Keywords: textile, Bronze Age, Southern Urals, imprints of textile.

The textile culture in the Late Bronze Age of the Southern Urals (Sintashta, Petrovka and Alakul cultures) is characterized by the employment of woolen fibers for manufacturing of woven and twisted textiles, dyeing with plant pigments, the use of the textiles for fabrication of costumes and in ceramic manufacture. Sintashta technologies demonstrate a rupture with the previous Eneolithic period. They have the closest parallels at Catacomb sites and were inherited by the Petrovka and Alakul people. During the first half of the $2^{\text {nd }}$ mill. $B C$, gradual change took place in the predominance of the types of textiles from the balanced ones in the Sintashta period to the thin unbalanced in the Alakul phase. The textile culture of the Southern Urals in the Late Bronze Age was a constituent of a single technological massif of the steppe and forest-steppe zone of the Srubnaya-Andronovo "world", as well as, possibly, also of the "Andronovoid" forest societies linked with the latter.

\section{МЕТАЛЛИЧЕСКИЕ ОРУДИЯ И ИЗДЕЛИЯ ФИНАЛА БРОНЗОВОГО ВЕКА ЮЖНОГО ЗАУРАЛЬЯ}

\author{
И. П. Алаева \\ Южно-Уральский государственный гуманитарно-педагогический университет, Челя- \\ бинск, Россия
}

DOI: $10.31600 / 978-5-907053-35-9-270-272$

Ключевые слова: финал бронзового века, черкаскульская культура, межовская культура, металлургический очаг.

В конце позднего бронзового века в Южном Зауралье происходит смена блока культур синташтинско-алакульского круга на свиту культурных образований андроноидного постандроновского блока. В лесостепной (на границе лесной) зоне появляется мощный блок андроноидных культур. В степной зоне формируется блок культур валиковой керамики. Территория Южного Зауралья становится пограничной зоной, расположенной на стыке этих образований.

Особое место на этой территории занимает черкаскульская культура, представленная в зонах и лесостепи, и степи. Существенную проблему составляет фактическое отсутствие набора культурноопределимых изделий. Набор предметов, характеризующих черкаскульско-межовские комплексы, составлялся из обширного перечня случайных находок (Обыденнов, Шорин 1995) и предметов, происходящих из многослойных поселений степной зоны (Матвеев 2007).

На лесостепном поселении Чебаркуль III обнаружен комплекс предметов финала бронзового века, отложившийся в слое с черкаскульской, межовской керамикой.

Медные однолезвийные ножи с рукоятью (рис. $1,1,4$ ). В типологии Н. А. Аванесовой однолезвийный нож с поселения Чебаркуль III наибольшую близость находит с категорией однолезвийных ножей типа Б - «черенковые» с намечающимся уступом, с ножом из Черноозерье 1, мог. 43 и мог. 126 (Аванесова 1991: рис. 33, 2).

Медные серпы-косари (рис. 1, 2, 3) относятся к категории серпов сосново-мазинского типа. Н. А. Аванесова относит подобные изделия к типу Г - секачи-косари, массивные серповидные изделия, имеющие широкую зону распространения. В. С. Бочкарёв и В. А. Дергачёв дают более подробную типологию серпов этого времени (Бочкарёв, Дергачёв 2002). Для обсуждаемого региона имеют распространение два типа Уральской группы: 